\title{
PERAN DESA PAKRAMAN DALAM MENYELESAIKAN SENGKETA TANAH ADAT DI DESA BUNGKULAN, KABUPATEN BULELENG
}

\author{
I Putu Prana Suta Arsadi, Ketut Sudiatmaka, Ratna Artha Windari \\ Jurusan IImu Hukum \\ Universitas Pendidikan Ganesha \\ Singaraja, Indonesia
}

e-mail: \{suta.arsadi, sudiatmaka, ratnawindari\}@undiksha.ac.id

\begin{abstract}
Abstrak
Penelitian ini bertujuan untuk mengetahui: (1) Bentuk sengketa tanah adat dan faktor yang menyebabkan terjadinya di Desa Bungkulan, Kecamatan Sawan, Kabupaten Buleleng (2) Peran Desa Pakraman Bungkulan dalam menyelesaikan sengketa tanah adat yang terjadi di Desa Bungkulan, Kecamatan Sawan, Kabupaten Buleleng (3) Kendala yang dihadapi oleh Desa Pakraman Bungkulan dalam menyelesaikan sengketa tanah yang terjadi di Desa Bungkulan, Kecamatan Sawan, Kabupaten Buleleng. Penelitian ini adalah penelitian yuridis empiris, dengan menggunakan pendekatan deskripif kualitatif. Hasil penelitian menunjukkan bahwa sengketa tanah adat yang terjadi di Desa Bungkulan dapat dikategorikan menjadi dua bentuk sengketa yaitu sengketa horizontal dan sengketa vertical. Sengketa tanah adat yang terjadi di Desa Bungkulan disebabkan oleh beberapa faktor yaitu: (a) Pengetahuan masyarakat mengena tanah masih kurang, terutama mengenai kepemilikan tanah adat; (b) Faktor ekonomi; (c) Masalah pewarisan; (d) Kurang jelasnya batas-batas tanah. Peran Desa Pakraman Bungkulan dalam menyelesaikan sengketa tanah adat yaitu dengan mengadakan mediasi yang dilakukan di Pura Desa Bungkulan dan dihadiri oleh (a) Prajuru Desa Pakraman Bungkulan; (b) Kerta Desa; (c) Kedua belah pihak yang bersengketa; (d) saksi-saksi. Adapun kendala yang dihadapi oleh Desa Pakraman Bungkulan dalam menyelesaikan sengketa tanah adat yang terjadi di Desa Bungkulan yaitu: (a) Adanya pihak-pihak yang bersengketa memiliki sifat yang egois;

(b) Sulit mencari saksi untuk memberikan keterangan; (c) Sulitnya mencari bukti-bukti yang diperlukan pada saat pemeriksaan.
\end{abstract}

Kata Kunci: Penyelesaian Sengketa, Prajuru Desa Pakraman.

\begin{abstract}
This research aims to deterwine (1) Forms of customary land dispute and factors that caused its occurrence in Bungkulan village, Sawan district, Buleleng regency, (2) The roles of Desa Pakraman Bungkulan in solving the dispute, and (3) Obstacles encountered by Desa Pakraman Bungkulan in solving it. This is an empirical juridical research with the use of descriptive qualitative approach. The results of this research show that the customary land dispute occurred in Bungkulan village can be categorized into two forms namely horizontal and vertical disputes. The disputes are caused by some factors, such as (a) lack of knowledge societies have about land, especially the ownership of customary land, (b) economic factor, (c) inheritance issue, and (d) lack of clarity of land boundaries. The role of Desa Pakraman Bungkulan in solving the disputes is conducting a mediation to solve the problem in a familial way. The mediation is done in Bungkulan village temple and attended by (a) Prajuru Desa Prakaman Bungkulan, (b) Kerta Desa, (c) both parties which are in dispute, and (d) witnesses. The obstacles which are faced by Desa Pakraman Bungkulan in resolving the customary land dispute are: (a) There are parties that are selfish, (b) It is difficult to
\end{abstract}


find witnesses to provide information; (c) It is difficult to seek for necessary evidence at the time of investigation.

Keywords: Dispute Resolution, Prajuru Desa Pakrama.

\section{PENDAHULUAN}

Tanah merupakan suatu aspek yang penting didalam kehidupan, dimana tanah mempunyai peran yang sangat penting dan merupakan pondasi utama dari seluruh kegiatan yang dilakukan oleh manusia. Tanah juga merupakan sumber penghidupan bagi manusia itu sendiri, setiap kegiatan yang dilakukan oleh manusia pasti berkaitan erat dengan tanah.

Di Bali hubungan manusia dengan alam sekitar sangat erat, bahkan ada upacara-upacara khusus yang dilakukan oleh masyarakat Bali untuk menjaga kesucian alam sekitar dimana masyarakat hidup dan mencari penghidupan. Dewasa ini seiring dengan perkembangan jaman makna dari palemahan yang terdapat pada filosofi Tri Hita Karana telah ternodai dengan banyaknya masyarakat yang serakah sehingga berdampak pada banyaknya kerusakan yang terjadi di alam sekitar. Jika dilihat disektor tanah banyak orang ingin mendapatkan hak atas tanah walau dengan cara apapun. Mulai dari yang membuat sertifikat ganda, mensertifikatkan tanah yang bukan menjadi hak miliknya sampai ada yang mengakui tanah-tanah yang dimiliki oleh desa adat.

Maraknya terjadi kasus-kasus dibidang tanah, disebabkan oleh faktorfaktor (1) Kurangnya tertibnya administrasi dibidang tanah dimasa lampau, (2) Kondisi masyarakat yang sudah semakin menyadari dan mengerti akan arti penting dan hak atas tanah yang dimilikinya, (3) Iklim keterbukaan sebagai salah satu kebijakan yang ditegaskan oleh pemerintah, (4) Masih banyaknya tanah- tanah yang belum bersertifikat, (5) Tanah yang dikuasai oleh seseorang belum tentu kepemilikannya ada pada orang yang menempati, (6) Proses pewarisan tanah tidak ditetapkan melaui mekanisme hukum,

(7) Masih adanya tanah yang penguasaannya secara komunal yang sewaktu-waktu dapat menimbulkankan konflik, (8) Adanya pihak-pihak yang menggunakan kesempatan untuk mencari keuntungan materil secara tidak wajar (Windari,2014:329).

Untuk menyelesaikan berbagai persoalan tanah yang terjadi di Bali sangat di perlukan adanya peranan yang aktif dari pihak Desa Pakraman yang ada di Bali. Selain untuk menyelesaikan sengketa tanah yang terjadi, peran Desa Pakraman ini sangat penting agar membantu para pihak yang bersengketa untuk menyelesaikan sengketa tanah yang terjadi. Desa Pakraman merupakan suatu kesatuan atau persekutuan wilayah yang berdasarkan atas kesatuan tradisi dan tatakrama pergaulan hidup yang diwarisi secara turun temurun serta diikat oleh Kahyangan Tiga yaitu Pura Desa, Pura Puseh, dan Pura Dalem.

Pada Desa Pakraman Bungkulan masih banyaknya terdapat kasus-kasus tentang tanah, selain dilatar belakangi oleh faktor ekonomi, juga dikarenakan masih lemahnya administrasi tanah. Kasus-kasus yang terjadi di Desa Pakraman Bungkulan tersebut sebagian besar telah di selesaikan melalui jalur non litigasi dalam hal ini pihak Desa Pakraman Bungkulan yang telah membantu dalam proses penyelesaian kasus tersebut melalui mediasi yang dilakukan oleh Prajuru Desa Pakraman beserta Kepala Desa Bungkulan dan melibatkan tokoh-tokoh masyarakat di Desa Pakraman Bungkulan.

Penelitian bertujuan untuk mengetahui Bentuk Sengketa Tanah Adat dan Faktor yang Menyebabkan Terjadinya di Desa Bungkulan, Kecamatan Sawan, Kabupaten Buleleng, untuk mengetahui peran Desa Pakraman Bungkulan dalam menyelesaikan sengketa tanah yang terjadi di Desa Bungkulan, Kecamatn Sawan, Kabupaten Buleleng dan untuk mengetahui Kendala yang Dihadapi oleh Desa Parkraman Bungkulan dalam menyelesaikan sengketa tanah yang terjadi di Desa Bungkulan, Kecamatan Sawan, Kabupaten Buleleng. 
Manfaat yang diperoleh dari penelitian ini adalah: Bagi pemerintah, hasil penelitian ini diharapkan dapat menjadikan konstribusi dalam membuat kebijakan mengenai penyelesaian sengketa tanah; Bagi Kantor Tanah Kabupaten Buleleng, hasil penelitian ini diharapkan dalam melakukan pendataan tanah pihak BPN harus melakukan kordinasi terlebih dahulu kepada masyarakat setempat; Bagi peneliti sejenis, dengan dilakukannya penelitian ini diharapkan bisa membantu bagi peneliti yang melakukan penelitian sejenis.

\section{METODE PENELITIAN}

Pada penelitian ini peneliti menggunakan kajian yuridis empiris. Kajian yuridis empiris di katakan sebagai law in action, dimana mengkaji hukum secara nyata,baik itu secara budaya maupun keadaan sosial. Dalam penelitian ini menggunakan dua jenis data yaitu data primer dan data sekunder. Pada penelitian ini data primer diperoleh langsung dari Prajuru Adat dan tokoh-tokoh adat yang mengetahui mengenai peran Desa Pakraman Bungkulan, Kepala Desa Bungkulan, Kecamatan Sawan, Kabupaten Buleleng seta masyarakat Desa Pakraman Bungkulan, Kecamatan Sawan, Kabepaten Buleleng, baik itu dari responden ataupun dari narasumber.

Teknik pengumpulan data adalah suatu cara yang digunakan oleh seseorang peneliti untuk mengumpulkan data - data baik berupa keterangan, : nilai - nilai ataupun angka - angka yang diperlukan dalam suatu penelitian (Elysabeth, 2001 : 48). Teknik penelitian yang digunakan pada penelitian ini yaitu (1) teknik studi dokumen yaitu memperoleh data dari buku, undangundang yang berkaitan dengan penelitian (Wibowo,2010:10). Teknik wawancara adalah suatu metode pengumpulan data yang dilakukan dengan cara melakukan percakapan dengan tujuan tertentu (Wibowo,2010:10). Teknik Observasi adalah pengamatan yang dilakukan secara sengaja dan sistematis mengenai fenomena social dengan gejala psikis untuk kemudian dilakukan pencatatan.
Penelitian ini merupakan penelitian kulaitatif dengan pendekatan yuridis empiris. Dimana dalam penelitian ini menganalisis dan mendeskripsikan mengenai Peran Desa Pakraman Bungkulan dalam menyelesaikan sengketa tanah adat yang terjadi di lapangan saat ini.

\section{HASIL DAN PEMBAHASAN}

Bisa dikatakan sangat beragam bentuk ataupun yang melatarbelakanginya (Wirantini,2014:27). Secara umum bentuk bentuk sengketa dilihat dari derajat atau tingkatan ekonomi orang yang bertikai (http://materiips.com/contoh-konflikhorizontal/amp) yaitu :

1. Sengketa horizontal, yaitu sengketa yang terjadi diantara orang atau golongan yang memiliki kesamaan derajat sosial, kelas sosial atau pun golongan yang sama dalam masyarakat.

2. Sengketa vertikal merupakan sengketa yang terjadi antara kelompok yang memiliki perbedaan strata tingkatan dalam masyarakat.

Berdasarkan pada hasil wawancara ditempat penelitian bahwa secara umum bentuk-bentuk sengketa tanah yang terjadi di Desa Bungkulan, Kecamatan Sawan, Kabupaten Buleleng yaitu:

1. Status kepemilikan

Pada jaman sekarang ini banyak sekali terjadi sengketa tanah karena tidak jelasnya status tanah tersebut. Terutama kepemilikan tanah-tanah jaman dulu yang belum mempunyai sertipikat. Hal tersebut sering sekali terjadi karena pemilik dari tanah tersebut masih enggan untuk mensertipikatkan tanah miliknya. Selain itu juga dikarenakan batasbatas tanah yang tidak jelas yang dapat menimbulkan sengketa tanah.

2. Pewarisan

Dimana pada jaman ini tanah sudah menjadi barang mewah yang memiliki nilai ekonomis yang tinggi. Dalam hal pewarisan sering kali sampai adanya perebutan tanah waris diantara para ahli warisnya, ada yang tidak terima dengan pembagian waris tidak merata antara ahli waris satu dengan ahli 
waris lainnya sehingga menimbulkan sengketa tanah dan juga ada ahli waris yang keberata akan sikap dari salah satu ahli waris yang menjual tanah warisan dari orang tuanya. Pada dasarnya tanah warisan itu tidak boleh dijual apabila tidak ada kebutuhan yang mendesak. Apabila tanah warisan tersebut dijual maka keturunan selanjutnya tidak bisa menikmati tanah warisan tersebut.

Jadi dari hal yang telah tersebut diatas dapat kita ketahui bahwa bentukbentuk sengketa tanah adat yang terjadi di Desa Bungkulan, Kecamatan Sawan, Kabupaten Buleleng ada 2 (dua) bentuk yaitu sengketa horizontal dan sengketa vertikal. Hal ini dapat dilihat dari bentukbentuk sengketa tanah adat secara umum yang telah terjadi di Desa Bungkulan, Kecamatan Sawan, Kabupaten Buleleng, yaitu: pada bentuk sengketa tanah adat mengenai status kepemilikan dapat dikategorikan sebagai sengketa horizontal maupun sengketa vertikal. Hal ini dapat dilihat dari sengketa tanah adat mengenai status kepemilikan, misalnya pada kasus yang terjadi di Banjar Adat Alasharum dimana terjadi kesalahpahaman antara pihak Desa Pakraman dengan pihak Banjar Adat mengenai status kepemilikan tanah adat hal tersebut dapat dikategorikan sebagai sengketa horizontal tetapi jika kita lihat pada sengketa yang terjadi di Pura Yeh Lembu dimana terjadi perebutan hak atas tanah antara orang perorangan dengan pihak Desa Pakraman Bungkulan sengketa ini dapat dikategorikan sebagai sengketa vertikal. Begitu pula pada sengketa mengenai pewarisan, apabila sengketa pewarisan tersebut terjadi pada orang dengan orang maka dapat dikategorikan sebagai sengketa horizontal. Berbeda halnya dengan sengketa pewarisan tanah adat apalagi sampai menjual warisan berupa tanah adat hal ini dapat dikategorikan sebagai sengketa vertikal, karena pada sengketa pewarisan tersebut tidak lagi antar perorangan tetapi antar orang dengan intansi adat yakni Desa Pakraman Bungkulan.

Suatu sengketa yang terjadi pada manusia bersumber pada berbagai macam sebab. Berbagai macam penyebab sengketa yang terjadi antar manusia, sehingga sangat sulit untuk mendeskripsikan secara jelas dan terperinci yang menjadi penyebab terjadinya sengketa. Hal ini disebabkan adanya sesuatu yang seharusnya menjadi penyebab terjadinya sengketa, tetapi pada kelompok manusia tertentu justru bukanlah hal yang menyebabkan terjadinya sengketa, demikian pula sebaliknya. Terkadang sesuatu yang sifatnya sepele dapat menjadi penyebab sengketa antara manusia. Suatu sengketa dilatarbelakangi oleh perbedaan ciri-ciri yang dibawa individu dalam suatu interaksi sosial. Dibawanya ciri-ciri individual dalam interaksi sosial, sengketa merupakan suatu situasi yang wajar terjadi pada masyarakat dan tidak ada satu masyarakat pun yang tidak pernah mengalami yang namanya sengketa, baik itu sengketa yang terjadi pada keluarganya, tempat kerja dan lingkungan tempat tinggalnya, sengketa hanya akan hilang bersamaan dengan hilangnya masyarakat itu sendiri (Wirantini,2014:26).

Adapun penyebab sengketa secara umum yaitu (Syahrifilani,2015:33):

1. Kesalahpahaman;

2. Perbedaan penafsiran;

3. Ketidakjelasan pengaturan;

4. Ketidakpuasan;

5. Ketersinggungan;

6. Kecurigaan;

7. Tindakan yang tidak patut, curang, tidak jujur;

8. Kesewenang-wenangan atau ketidak adilan;

9. Keadaan yang tidak terduga.

Jika dilihat pada tempat penelitian dari banyaknya sengketa tanah adat yang terjadi di Desa Bungkulan, Kecamatan Sawan, Kabupaten Buleleng diakibatkan oleh beberapa faktor-faktor yang memcu terjadinya sengketa tanah adat di Desa Bungkulan. Adapun faktor-faktor menyebabkan terjadinya sengketa tanah adat di Desa Bungkulan, Kecamatan Sawan, Kabupaten Buleleng yaitu:

1. Pengetahuan masyarakat mengenai kepemilikan tanah adat masih kurang Dimana masyarakat masih kurang pengetahuannya akan tanah adat, terutama masih adanya masyarakat yang belum tahu bahwa tanah adat 
merupakan harta kekayaan Desa Pakraman. Sehingga semua tanah adat yang berada di wilayah Desa Pakraman tersebut merupakan aset yang dimiliki oleh Desa Pakraman dan tidak boleh disertipikatkat maupun diperjualbelikan.

2. Adanya niat untuk menguasai

Terkadang di suatu keluarga dalam hal pewarisan pasti ada salah satu dari ahli waris yang ingin menguasai tanah warisan tersebut. Apabila ahli waris itu merasa dirinya mapan dari segi ekonomi maka ia akan berbuat semena-mena.

3. Faktor ekonomi

Di jaman sekarang ini tanah memiliki harga jual yang sangat tinggi hal ini dikarenakan luas tanah tidak sebanding dengan jumlah penduduk di Desa Bungkulan. Hal ini dapat menimbulkan terjadinya sengketa, karena ada pihak yang hendak menguasai tanah dengan cara yang tidak baik, seperti pembuatan sertipikat palsu dan lain sebagainya. Desa Bungkulan merupakan salah satu desa terpadat yang ada di Kabupaten Buleleng, dimana Desa Bungkulan ini memiliki 13 dusun dengan jumlah penduduk mencapai

15.108 jiwa. Hal ini berdampak pada harga tanah yang ada di Desa Bungkulan, karena angka jumlah penduduk yang ada di Desa Bungkulan sangat tinggi sedangkan luas wilayah Desa Bungkulan tidak sebanding dengan jumlah penduduk sehingga tanah yang ada di Desa Bungkulan memiliki nilai ekonomi yang tinggi. Meningkatnya nilai ekonomi tanah hal ini akan menimbulkan terjadinya perebutan hak atas tanah, karena nilai tanah yang tinggi orang tidak akan menyia-nyiakan tanah miliknya dan bahkan akan melindungi hak atas tanah miliknya. Hal ini yang menyebabkan mengapa faktor ekonomi merupakan faktor yang menimbulkan terjadinya sengketa tanah yang terjadi di Desa Bungkulan.

4. Faktor Pewarisan

Masalah pewarisan ini merupakan masalah yang paling sering terjadi. Tidak hanya disebabkan oleh pembagian waris yang tidak merata tetapi adanya ketidakcocokan diantara ahli waris tersebut sehingga dapat memicu terjadinya sengketa.

5. Kurang jelasnya batas-batas tanah Hal ini dikarenakan apabila batas tanahnya tidak jelas maka bisa terjadi saling klaim antara orang yang satu dengan orang yang lain atau orang dengan intansi Desa Bungkulan maupun dengan intansi Desa Pakraman. Terutama yang jarak tanahya berdekatan hal ini sangat riskan sekali terjadi saling mengklaim hak atas tanah tersebut.

Dari berbagai konflik tanah adat yang terjadi di Desa Bungkulan, Kecamatan Sawan, Kabupaten Buleleng jika dikaitkan teori konflik yang ada, kondisi yang dihadapi oleh masyarakat Desa Bungkulan sesuai dengan teori konflik yakni kebutuhan manusia sebagai salah satu penyebab timbulnya suatu konflik dalam masyarakat (Windari,2014:336). Hal ini karena tanah merupakan kebutuhan masyarakat Desa Bungkulan yang sangat penting, baik itu untuk membangun rumah, untuk mencari penghasilan seperti berkebun, sawah dan membuka usaha. Ini yang menyebabkan tanah memiliki nilai ekonomi yang tinggi. Konflik tanah yang terjadi di Desa Bungkulan, Kecamatan Sawan, Kabupaten Buleleng pada dasarnya muncul akibat adanya perebutan sumberdaya yang dianggap berharga dan memiliki nilai ekonomi yang tinggi.

Maka dari hal tersebut dapat kita lihat bahwa adapun faktor-faktor yang menjadi penyebab terjadinya sengketa tanah adat di Desa Bungkulan, Kecamatan Sawan, Kabupaten Buleleng dipicu oleh berbagai hal, yaitu:

1. Pengetahuan masyarakat mengenai tanah masih kurang, terutama mengenai kepemilikan tanah adat;

2. Adanya niat untuk menguasai;

3. Faktor ekonomi;

4. Masalah pewarisan;

5. Kurang jelasnya batas-batas tanah.

Di Bali mengenal adanya sistem pemerintahan dua desa, dimana desa yang ada di Bali mengandung dua arti ( di dalam Suartha,2015:45) yaitu:

1. Desa Adat, kesatuan daerah dimana penduduknya bersama-sama atas 
tanggungan bersama (krama desa) melakukan suatu ibadat, dengan tujuan untuk menjaga kesucian tanah desa (groundmagis) serta memelihara purapura (tempat ibadah-tempat ibadah) yang ada di suatu desa (Suartha,2015:45);

2. Desa Dinas,suatu teritorium (daerah) pemerintahan. Jadi, Desa Dinas ini dibentuk oleh pemerintah, dan berdasarkan Undang-undang Pemerintah Daerah diberi label desa otonom (Suartha,2015:44).

Berikut beberapa regulasi yang berpihak pada hak masyarakat adat adalah sebagai berikut:

1. Undang-Undang Nomor 6 Tahun 2014 tentang Desa:

(1) Pasal 103 huruf b berbunyi bahwa desa adat berwenang mengatur dan mengurus tanah ulayat atau wilayah adat.

2. Pasal 6 Undang-Undang Nomor 39 Tahun 1999 tentang Hak Asasi Manusia yang berbunyi:

(1) Dalam rangka penegakan hak asasi manusia, perbedaan dan kebutuhan dalam masyarakat hukum adat harus diperhatikan dan dilindungi oleh hukum, masyarakat dan pemerintah.

(2) Identitas budaya masyarakat hukum adat, termasuk hak atas tanah ulayat dilindungi, selaras dengan perkembangan jaman.

3. Undang-Undang Nomor 5 Tahun 1960 tentang Pokok-Pokok Agraria (UUPA).

(1) Pasal 3 menyebutkan bahwa dengan mengingat ketentuan-ketentuan dalam Pasal 1 dan 2 pelaksanaan hak-ulayat dan hak-hak yang serupa itu dari masyarakat-masyarakat hukum adat, sepanjang menurut kenyataannya masih ada, harus sedemikian rupa sehingga sesuai dengan kepentingan nasional dan Negara, yang berdasarkan atas persatuan bangsa serta tidak boleh bertentangan dengan undangundang dan peraturan-peraturan lain yang lebih tinggi.

(2) Pasal 5 menyebutkan bahwa hukum agraria yang berlaku atas bumi, air dan ruang angkasa ialah hukum adat, sepanjang tidak bertentangan kepentingan nasional dan Negara, yang berdasarkan atas persatuan bangsa, dengan sosialisme Indonesia serta dengan peraturan- peraturan yang tercantum dalam undangundang ini dan dengan peraturan perundang-undangan lainnya, segala sesuatu dengan mengindahkan unsur-unsur yang bersandar pada hukum agama.

(3) Penjelasan Pasal 5 dan Penjelasan umum II (1) UUPA berisi penegasan bahwa hukum adat merupakan hukum asli Indonesia yang dijadikan dasar hukum agrarian

(Windari,2014:335).

(4) Pasal 21 ayat (2) menyatakan bahwa oleh pemerintah ditetapkan badanbadan hukum yang dapat mempunyai hak milik dan syarat- syaratnya.

(5) Pasal 49 ayat (1) beserta penjelasannya yang menyatakan bahwa hak milik badan-badan keagamaan dan sosial sepanjang dipergunakan untuk usaha dalam bidang keagamaan dan sosial diakui dan dilindungi. Berdasarkan pasal ini secara tegas telah memberikan perlindungan dan pengakuan terhadap hak milik atas tanah badanbadan keagamaan hak Desa Adat.

4. Pasal 1 huruf c Peraturan Pemerintah Nomor 38 Tahun 1963 tentang Penunjukan Badan-Badan Hukum yang Dapat Mempunyai Hak Milik Atas Tanah adalah Badan-Badan Keagamaan (termasuk juga Desa Adat).

5. Perda Nomor 6 Tahun 1986 tentang Desa Adat yang telah diganti dengan Perda Nomor 3 Tahun 2001, dan diubah dengan Perda Nomor 3 Tahun 2003 tentang Desa Pakraman.

(1) Pasal 1 butir 4, menyatakan bahwa Desa Pakraman adalah kesatuan masyarakat hukum adat di Propinsi Bali yang mempunyai satu kesatuan tradisi dan tata karma pergaulan hidup masyarakat umat Hindu secara turun temurun dalam ikatan Kahyangan Tiga atau Kahyangan Desa yang mempunyai wilayah tertentu dan harta kekayaan sendiri serta berhak mengurus rumah tangganya sendiri. 
(2) Pasal 9 menyebutkan bahwa harta kekayaan Desa Pakraman adalah kekayaan yang telah ada maupun yang akan ada, pengelolaan harta kekayaan dilakukan oleh prajuru desa sesuai awig-awig Desa Pakraman masing-masing, setiap pengalihan atau perubahan status harta kekayaan tersebut dilakukan oleh Krama Desa Pakraman.

Dari beberapa regulasi tentang tanah tersebut pada prinsipnya memberikan suatu pengakuan, perlindungan dan penghormatan terhadap hak-hak yang dimiliki oleh masyarakat adat. Hal tersebut berdasarkan pada amanat yang terkandung dalam UUD 1945 sebagai konstitusi atau dasar hukum dari bangsa Indonesia yang mengakui keberadaan masyarakat adat beserta hak dan kewajibannya (Windari,2014:336). Dari penjabaran yang telah tersebut diatas hal ini menandakan regulasi tentang tanah memiliki keberpihakan terhadap hak-hak yang dimiliki oleh masyarakat adat, khususnya terkait kepemilikan hak atas tanah adat, dan dari hal regulasi diatas dapat dilihat bahwa desa adat memiliki kewenangan dalam mengurus rumah tangganya sendiri termasuk juga untuk menyelesaikan sengketa-sengketa yang terjadi di wilayah desa adat tersebut.

Di Bali sebutan untuk Desa Adat yaitu Desa Pakraman. Dalam Pasal 1 angka 4 Perda Propinsi Bali No 3 Tahun 2001 tentang Desa Pakraman menyatakan bahwa yang dimaksud dengan Desa Pakraman adalah kesatuan masyarakat hukum adat di Propinsi Bali yang mempunyai satu-kesatuan tradisi dan tata krama pergaulan hidup masyarakat umat Hindu secara turun temurun dalam ikatan kahyangan tiga atau kahyangan desa yang mempunyai wilayah tertentu dan harta kekayaan sendiri serta berhak mengurus rumah tangganya sendiri. Desa Pakraman memiliki tugas-tugas tersendiri, hal ini dapat dilihat pada Pasal 5 Perda No. 3 Tahun 2001 tugas dari Desa Pakraman adalah:

1. Membuat awig - awig;

2. Mengatur krama desa;

3. Mengatur pengelolaan harta kekayaan desa;
4. Bersama - sama pemrintah melaksanakan pembangunan dari segala bidang terutama dibidang keagamaan, kebudayaan, dan kemasyarakatan;

5. Membina dan mengembangkan nilai nilai budaya Bali dalam rangka memperkaya, melestarikan dan mengembangkan kebudayaan, nasional pada umumnya dan kebudayaan daerah pada khususnya;

6. Mengayomi krama desa.

Desa Pakraman Bungkulan sangat besar perannya dalam menyelesaikan sengketa tanah terutama yang menyangkut tanah adat seperti tanah Ayahan Desa, tanah Pekarangan Desa, tanah Laba Pura. Desa Pakraman Bungkulan berdasarkan wewenang yang dimilikinya berhak untuk menyelesaikan segala permasalahan yang terjadi di wilayahnya secara kekeluargaan. Sesuai pada data yang telah diperoleh ditempat penelitian bahwa Desa Pakraman memiliki peran yang sangat penting dalam menyelesaikan sengketa tanah yang sesuai dengan kewenangan yang dimiliki oleh Desa Pakraman yaitu untuk menyelesaikan sengketa tanah adat, sehingga Desa Pakraman Berhak turut serta dalam menyelesaikan sengketa tanah adat yang ada di wilayahnya.

Peran Desa Pakraman Bungkulan dalam menyelesaikan sengketa tanah di Desa Bungkulan ini yaitu dengan cara mengadakan mediasi agar sengketa yang terjadi dapat diselesaikan secara kekeluargaan. Sesuai pada data yang diperoleh pada tempat penelitian tujuan dilakukannya mediasi oleh Desa Pakraman Bungkulan dalam menyelesaikan sengketa tanah yang terjadi di Desa Bungkulan yaitu:

1. Hal ini sesuai dengan tugas dan kewajiban dari Prajuru Desa Pakraman dalam menjaga ketertiban di wilayah Desa Pakraman Bungkulan (sukerta tata pawongan).

2. Memberikan rasa keadilan pada krama desa agar krama desa paham mengenai tanah-tanah yang dimiliki oleh Desa Pakraman. 
Para pihak yang ikut serta dan hadir dalam mediasi yang dilakukan oleh Desa Pakraman Bungkulan yaitu:

1. Tim Kerta Desa;

2. Prajuru Desa Pakraman;

3. Para pihak yang bersengketa

4. Saksi-saksi

5. Pihak Kabupaten terkadang juga mengikuti pelaksanaan mediasi yang dilakukan oleh Desa Pakraman Bungkulan.

Mediasi yang dilakukan oleh Desa Pakraman Bungkulan dalam menyelesaikan sengketa tanah yang terjadi di Desa Bungkulan dilakukan di Pura Desa Bungkulan. Tujuan mengapa pelaksanaan mediasi terebut dilakukan di Pura Desa Bungkulan, hal ini dikarenakan pihak Desa Pakraman Belum mempunyai sekretariat khusus untuk melakukan mediasi dengan para pihak yang bersengketa, selain itu mengapa dipilih di Pura Desa karna letaknya yang strategis dan sebelum melakukan mediasi pihak Prajuru Desa Pakraman dan para pihak yang bersengketa akan mengadakan persembahyangan terleih dahulu agar pelaksanaan mediasi dapat berjalan lancar.

Sengketa tanah yang dapat diselesaikan oleh Desa Pakraman Bungkulan yaitu sengketa tanah adat. Sengketa tanah adat ini ada yang berupa horizontal dan vertikal. Suatu sengketa tanah adat yang dikatakan horizontal apabila sengketa tersebut terjadi pada orang-perorangan. Sedangkan sengketa vertikal merupakan sengketa yang terjadi antara orang perorangan dengan Desa Pakraman.

Adapun proses pelaksanaan mediasi yang diakukan oleh Desa Pakraman Bungkulan berdasarkan hasil wawancara di lapangan dapat diketahui ada beberapa tahapan dalam pelaksanaan mediasi. Pada proses pelaksanaan mediasi yang dilakukan oleh Desa Pakraman Bungkulan dalam menyelesaiakan sengketa tanah adat, baik itu berbentuk sengketa horizontal maupun sengketa vertical memiliki proses penyelesaian yang sama. Adapun tahapan pelaksanaan proses mediasi yang dilakukan oleh Desa Pakraman Bungkulan dalam menyelesaikan sengketa tanah adat yang terjadi di Desa Bungkulan yaitu:

1. Pelaksanaan mediasi dilakukan oleh Desa Pakraman Bungkulan apabila adanya laporan dari pihak yang merasa dirugikan (Pesadok).

2. Setelah adanya laporan masuk dari pihak yang merasa dirugikan (Pesadok) kemudian laporan tersebut diperiksa oleh pihak Desa Pakraman Bungkulan untuk mengetahui apakah benar terjadi sengketa sesuai dengan apa yang telah dilaporkan.

3. Laporan yang diajukan oleh pihak yang merasa dirugikan tidak hanya berupa laporan secara lisan saja, tetapi harus dilengkapi oleh surat yang dibuat oleh pihak pelapor yang ditujukan kepada Kelian Desa Pakraman Bungkulan.

4. Setelah itu Desa Pakraman Bungkulan membentuk tim (Kerta Desa) untuk memeriksa dan mengevaluasi laporan yang telah masuk.

5. Kemudian tim yang telah dibentuk oleh Desa Pakraman Bungkulan ini (Kerta Desa) melakukan perencanaan untuk menyelesaikan masalah itu (nepasin wicara) berdasarkan awig-awig yang berlaku di Desa Pakraman Bungkulan.

6. Dibuatkan surat pemanggilan untuk kedua belah pihak yang bersengketa beserta saksi-saksi yang akan memberikan keterangan dan surat-surat seperti sertipikat untuk dijadikan bukti kepemilikan tanah.

7. Kemudian dilakukan Paruman (mediasi) yang dilakukan oleh Kerta Desa yang dihadiri oleh oleh Prajuru Desa Pakraman Bungkulan, Kerta Desa, saksi-saksi dan kedua belah pihak yang bersengketa.

8. Setelah dilakukannya Paruman (mediasi) maka selanjutnya para Kerta Desa akan memberikan keputusan atas permasalahan yang terjadi. Dasar-dasar pertimbangan bagi Kerta Desa dalam memberikan keputusan yaitu awig-awig yang berlaku di Desa Pakraman Bungkulan. Bila masih ada waktu maka pada hari itu juga akan diputuskan, tetapi apabila karna tidak cukup waktu maka data-data yang ada akan dikaji dahulu oleh Kerta Desa kemudian akan dicarikan waktu untuk mengadakan Paruman (mediasi) kembali. 
9. Kemudian Kerta Desa memberikan keputusan atas permasalahan yang terjadi. Apabila keputusan yang dikeluarkan oleh Kerta Desa tersebut tidak diterima oleh kedua belah pihak yang bersengketa, maka akan dilakukan Paruman (mediasi) ulang untuk memberikan putusan yang baru.

10. Setelah diberikan keputusan yang baru oleh Kerta Desa, apabila masih tidak diterima oleh para pihak yang bersengketa maka, pihak Prajuru Desa Pakraman Bungkulan akan menyerahkan kembali kepada para pihak yang bersengketa dan akan diselesaikan berdasarkan hukum positif.

Pada bagian akhir isi putusan yang dikeluarkan oleh Desa Pakraman tersebut berisi:

"Bilamana bagi para pihak yang bersengketa tidak puas akan Putusan Desa Pakraman ini dapat dilanjutkan melalui pengadilan".

Dari hal tersebut dapat dilihat bahwa para pihak yang bersengketa telah diberikan suatu kebebasan untuk menerima putusan dari Desa Pakraman tersebut atau ingin dilanjutkan ke jalur litigasi (pengadilan). Sehingga tidak ada paksaan dari pihak Desa Pakraman untuk mengikuti isi putusan yang telah dikeluarkan oleh Desa Pakraman Bungkulan.

Peran aktif dari Desa Pakraman Bungkulan dalam menyelesaikan sengketa tanah adat di Desa Bungkulan, Kecamatan Sawan, Kabupaten Buleleng berdasarkan pada awig-awig dan dresta (kebiasaan) yang berlaku di Desa Pakraman Bungkulan. Pada awig-awig yang berlaku di Desa Pakraman Bungkulan telah tercantum secara jelas yaitu:

1. Pawos 55 ayat (1) awig-awig Desa Pakraman Bungkulan "sane wenang mawosin miwah mutusang wicara ring krama desa inggih punika"( artinya bahwa yang berwenang dalam menyelesaikan dan memberikan keputusan dari masalah yang terjadi pada karma desa adalah) :

a. I Kelian Banjar Pakraman prade sang mawicara sane patunggilan banjar pakraman (artinya Kepala Banjar
Pakraman yang berwenang mengatasi masalah di Banjar Pakraman).

b. I Kelian Desa Pakraman prade sang mawicara sami-sami patunggilan Desa Pakraman (artinya Kepala Desa Pakraman yang berwenang mengtasi masalah di Desa Pakraman).

2. Pawos 55 ayat (2) awig-awig Desa Pakraman Bungkulan "dudonan mawosin saha muputang wicara krama desa sekadi ring sor" (artinya menyampaikan susunan untuk menyelesaikan masalah masyarakat desa seperti di bawah ini) :

a. Kaping ajeng kebawosin oleh Kelian Banjar Pakraman (pertama dibicarakan oleh Kelian Desa Pakraman);

b. Tan cumpu ring panepas Kelian Banjar Pakraman katunasang ring Pangelingsir Banjar Pakraman (artinya apabila tidak bisa diselesaikan oleh Kelian Banjar Pakraman baru meminta bantuan kepada tokoh yang ada di Desa Pakraman);

c. Paruman Banjar Pakraman tan kanutin kengin nunasang ring Kelian Desa Pakraman (artinya apabila dalam musyawarah Desa Pakraman tidak bisa diselesaikan maka meminta bantuan kepada Kelian Desa Pakraman);

d. Kelian Desa Pakraman tan prasida muputang katincapang ring Kerta Desa maka wasaning pamutus (apabila Kelian Desa Pakraman tidak dapat menyelesaikan maka akan ditingkatkan pada Kerta Desa untuk memutuskan).

3. Pawos 55 ayat (3) awig-awig Desa Pakraman Bungkulan "prade sang mawicara tan wenten cumpu ring pamutus Kerta Desa kengin mawosang wicara inucap ring sang rumawos (pengadilan negeri)" (artinya apabila dalam musyawarah tidak dapat diputuskan oleh Kerta Desa maka dapat diselesaikan melalui pengadilan).

4. Pawos 56 ayat (1) awig-awig Desa Pakraman Bungkulan "sahanan wicara sane mawiwit kecorahan sane sinanggeh nungkasin daging awig-awig miwah perarem Desa, patut digelis kebawosin yadiastun durung wenten 
pesadok" (artinya pembicaraan yang buruk yang bertentangan dengan awigawig dan muswayarah desa, harus cepat ditangani walaupun belum ada laporan).

5. Pawos 56 ayat (2) awig-awig Desa Pakraman Bungkulan "sejaba wicara inucap ring ajeng patut nyantos pesadok saking sang nunas bawos" (artinya segala pembicaraan tersebut diatas harus menunggu laporan dari.

6. Pawos 56 ayat (3) awig-awig Desa Pakraman Bungkulan "penepase patut pastika nyantenang iwang kalawan patut malarapan antuk Tri Premana (saksi, ilakita, bukti) miwah nepek ring dresta (memutuskan benar atau salah berdasarkan Tri Permana (bukti, saksi, surat).

Dari hal tersebut jelas terlihat bahwa selain regulasi tentang tanah yang berlaku di Indonesia yang telah menyatakan bahwa hak-hak adat tetap diakui, dijaga, dan dihormati keberadaannya. Maka dari itu Desa Pakraman diberikan suatu kewenangan untuk mengatur rumah tangganya sendiri dan menyelesaikan permasalahan-permasalahan yang terjadi di wilayahnya termasuk juga untuk menyelesaikan sengketa tanah adat berdasarkan pada awig-awig yang berlaku di Desa Pakraman tersebut.

Adanya peran aktif dari Desa Pakraman dalam menyelesaikan sengketa tanah adat sangat penting, karena sekali keuntungan yang diperoleh apabila sengketa tanah adat diselesaikan oleh Desa Pakraman, misalnya:

1. Proses penyelesaian sengketa tanah adat tersebut dilakukan secara kekeluargaan dan nantinya setelah sengketa tersebut tidak ada rasa dendam dari kedua belah pihak.

2. Apabila sengketa yang dihadapi itu merupakan sengketa tanah adat alangkah lebih baik diselesaikan terlebih dahulu pada Desa Pakraman karna tiap-tiap Desa Pakraman memiliki ciri khasnya tersendiri apalagi mengenai masalah tanah adat.

3. Penyelesaian sengketa tanah adat melalui Desa Pakraman tidak memerlukan proses administrasi yang cukup banyak menyita waktu.
Adanya peran aktif dari Desa Pakraman dalam menyelesaikan sengketa tanah adat sangat penting, karena apabila kedua belah pihak tidak puas akan putusan yang dikeluarkan oleh Desa Pakraman dan kedua belah pihak tersebut sepakat untuk menyelesaikan sengketa yang sedang dihadapinya di Pengadilan Negeri makan putusan yang telah dikeluarkan oleh Desa Pakraman dijadikan bahan pertimbangan bagi hakim untuk memberikan putusan. Terutama pada saat persidangan yang menjadi hakim tersebut tidak mengetahui bagaimana hukum adat yang berlaku khususnya di tempat terjadinya sengketa maka Kelian Desa Pakraman akan diminta untuk menjadi saksi ahli, karena Kelian Desa Pakraman mengetahui secara jelas bagaimana hukum adat yang berlaku diwilayahnya.

Dengan adanya peran dari Desa Pakraman Bungkulan dalam menyelesaikan sengketa tanah adat yang terjadi di Desa Bungkulan sudah dapat dikatakan berhasil. Hal ini karena sudah banyak sengketa tanah adat yang diselesaikan, walaupun ada pihak yang keberatan dan harus diselesaikan melalui pengadilan putusan yang telah dikeluarkan dijadikan bahan pertimbangan oleh hakim dan bahkan Prajuru Desa Pakraman Bungkulan dipanggil sebagai saksi ahli dalam persidangan tersebut. Terlepas dari pada itu, berdasarkan hasil penelitian di lapangan bahwa penyelesaian sengketa tanah adat yang dilakukan oleh Desa Pakraman Bungkulan menemui beberapa hambatan, diantaranya adalah:

1. Adanya pihak-pihak yang bersengketa memiliki sifat yang egois dan cendung mempertahankan pendapatnya sendiri dan tidak mau mengalah.

Jika ada pihak yang memiliki sifat yang egois memang agak sulit dalam hal perundingan dan menanyakan kronologi penyebab sengketa yang terjadi tersebut. Selain itu hal ini berdampak pada lamanya waktu yang diperlukan dalam menyelesaikan sengketa tanah adat yang terjadi.

2. Sulit mencari saksi untuk memberikan keterangan.

Kesulitan dalam mencari saksi merupakan kendala yang paling sering tejadi, hal ini dikarenakan masyarakat 
enggan untuk mau menyampaikan apa yang ia ketahui mengenai sengketa yang terjadi karna adanya rasa takut sehingga masyarakat enggan. Selain itu masyarakat juga selalu memikirkan untung rugi bila menjadi saksi, karna tidak ada keuntungan yang didapat sehingga masyarakat lebih memilih untuk melanjutkan pekerjaan yang ia lakukan dari pada memenuhi panggilan sebagai saksi untuk memberikan keterangan.

3. Sulitnya mencari bukti-bukti yang diperlukan pada saat pemeriksaan. Kesulitan mencari bukti-bukti terutama bukti-bukti tertulis merupakan salah satu kendala yang sering dihadapi oleh Desa Pakraman Bungkulan. Hal ini dikarenakan sengketa tanah yang diselesaikan oleh Desa Pakraman Bungkulan merupakan tanah adat meliputi tanah Pekarangan Desa, tanah Ayahan Desa dan lain sebagainya. Dimana tanah adat merupakan tanah yang sering tidak ada sertipikatnya sehingga sulit untuk membuktikan saat ada sengketa.

Untuk mengatasi hambatanhambatan yang ditemui oleh Desa Pakraman Bungkulan dalam menyelesaikan sengketa tanah adat di Desa Bungkulan dengan dilakukan beberapa cara. Adapun cara-cara yang dapat dilakukan untuk mengatasi kendalakendala yang dihadapi yaitu:

1. Untuk mengatasi kendala adanya pihak-pihak yang bersengketa memiliki sifat yang egois dan cendung mempertahankan pendapatnya sendiri dan tidak mau mengalah, dilakukan dengan cara mengadakan pembinaan dan pendekatan. Selain itu sebelum pelaksanaan mediasi dilakukan Prajuru Desa Pakraman beserta para pihak yang bersengketa melakukan persembahyangan bersama. Hal ini bertujuan supaya pelaksanaan mediasi dapat berjalan lancer dan para pihak mengikuti proses mediasi dengan tenang dan jujur dalam memberikan keterangan terkait sengketa yang sedang dihadapi.

2. Dalam mengatasi kendala sulitnya mencari saksi untuk memberikan keterangan pihak Desa Pakraman
Bungkulan akan berupaya secara maksimal untuk mencari saksi-saksi untuk dimintai keterangannya tentang sengketa yang sedang dihadapi. Apabila tidak berhasil menemukannya maka Desa Pakraman Bungkulan akan mencari orang-orang yang memang berkompeten dibidang sengketa yang sedang dihadapi untuk dimintai bantuan dalam menyelesaikan sengketa yang sedang terjadi.

3. Dalam mengatasi kendala sulitnya mencari bukti-bukti yang diperlukan pada saat pemeriksaan pihak Desa Pakraman Bungkulan akan menelusuri silsilah keluarga pemilik tanah sebelumnya.

\section{PENUTUP}

Bentuk sengketa tanah adat yang terjadi di Desa Bungkulan dapat dikategorikan menjadi 2 (dua) bentuk sengketa tanah yaitu sengketa tanah horizontal dan sengketa tanah vertikal. Adapun faktor-faktor yang menyebabkan terjadinya sengketa tanah adat di Desa Bungkulan yaitu: (a) Pengetahuan masyarakat mengena tanah masih kurang; (b) Adanya niat untuk menguasai; (c) Faktor ekonomi; (d) Masalah pewarisan; (e)Kurang jelasnya batas-batas tanah.

Peran Desa Pakraman Bungkulan dalam menyelesaikan sengketa tanah adat di Desa Bungkulan yaitu menyelesaikan sengketa tanah melalui mediasi. Mediasi yang dilakukan oleh Desa Pakraman Bungkulan bertujuan agar dapat menyelesaikan sengketa secara kekeluargaan. Pelaksanaan mediasi ini dilakukan di Pura Desa Bungkulan agar sebelum dilakukannya mediasi Prajuru Desa Pakraman dan para pihak yang bersengketa dapat melakukan persembahyangan bersama. Dalam mediasi ini dihadiri oleh beberapa pihak, yaitu: (a) Tim Kerta Desa; (b) Prajuru Desa Pakraman; (c) Para pihak yang bersengketa; (d) Saksi-saksi; (e) Pihak Kabupaten terkadang juga mengikuti pelaksanaan mediasi yang dilakukan oleh Desa Pakraman Bungkulan.

Kendala yang dihadapi oleh Desa Pakraman Bungkulan dalam menyelesaikan sengketa tanah yaitu: (a) Adanya pihak-pihak yang bersengketa 
memiliki sifat yang egois; (b) Sulit mencari saksi; (c) Sulitnya mencari bukti-bukti. Untuk mengatasi kendala yang dihadapi oleh Desa Pakraman Bungkulan dilakukan dengan beberapa cara yaitu: (a) mengadakan pembinaan dan pendekatan serta melakukan persembahyangan; (b) meminta bantuan kepada para tokoh masyarakat yang ahli dibidang permasalahan yang sedang dihadapi; (c) menelusuri silsilah keluarga pemilik tanah sebelumnya.

Kepada Pemerintah Kabupaten Buleleng diharapkan agar ikut serta dalam membantu menjaga keberadaan tanah adat sebagai salah satu harta kekayaan yang dimiliki oleh Desa Pakraman agar jangan sampai tanah adat yang ada hilang karena telah beralih satus menjadi tanah hak milik. Selain itu pihak Pemerintah Kabupaten Buleleng juga harus memperhatikan kesejahteraan para Prajuru Desa Pakraman yang telah mengabdi di Desa Pakraman supaya tidak seperti sekarang ini para Prajuru Desa Pakraman harus menggunakan uang pribadinya untuk keperluan Desa Pakraman. Kepada masyarakat (krama) Desa Pakraman Bungkulan agar bersama- sama menjaga dan mempelajari hak-hak tanah adat supaya mengetahui mengai hak-hak atas tanah adat yang ada diwilayah Desa Pakraman Bungkulan.

\section{DAFTAR PUSTAKA}

Ady Wibowo, Rayi.2010.Penyelesaian Sengketa Tanah Di Kecamatan Karanganyar Melalui Mediasi Oleh Kantor Pertanahan Kabupaten Karanganyar.Surakarta:Universitas Sebelas Maret. (diakses tanggal 24 Agustus 2017)

http://materiips.com/contoh-konflikhorizontal/amp (diakses tanggal 13 Oktober 2017)

Peraturan Daerah Propinsi Bali Nomor 3 Tahun 2001 tentang Desa
Pakraman.Lembaran

Daerah

Provinsi Bali Tahun 2001 Nomor 29 Seri D Nomor 29.

Peraturan Pemerintah Nomor 38 Tahun 1963 tentang Penunjukan BadanBadan Hukum yang Dapat Mempunyai Hak Milik Atas Tanah.Lembaran Negara Republik Indonesia Tahun 1963 Nomor 61.

Suartha, I Dewa Made.2015. Hukum Dan Sanksi Adat.Malang:Selara Press

Syahrifilani.2015.Analisis Hukum Terhadap Sengketa Hak Atas Tanah Oleh Pengurus Besar Darud DA'WAH WAL-IRSYAD(PB-DDI) Dengan Universitas ASY'Ariah

Mandar.Makasar:Universitas Hasanuddin. (diakses tanggal 19 Agustus 2017)

Undang-Undang Dasar Tahun 1945

Undang-Undang Nomor 5 Tahun 1960 tentang Peraturan Dasar Pokok Agraria.Lembaran Negara Republik Indonesia Tahun 1960 Nomor 104.

Undang-Undang Nomor 39 Tahun 1999 tentang Hak Asasi Manusia. Lembaran Negara Republik Indonesia Tahun 1999 Nomor 138, Tambahan Lembaran Negara Republik Indonesia Nomor 3872.

Windari, Ratna Artha.2014.Keberpihakan Regulasi Tanah Terhadap Hak Masyarakat Adat (Studi Sengketa Tanah Adat di Desa Kubutambahan, Kecamatan Kubu Tambahan, Kabupaten Buleleng.Jurnal IImu Sosial dan Humaniora.Vol. 3, No. 1 (diakses tanggal 2 Oktober 2017) Wirantini, Luh.2014.Sengketa Tanah Setra Karang Rupit Di Desa Pakraman Temukus, Kecamatan Banjar, Kabupaten

Buleleng.Singaraja:Universitas

Pendidikan Ganesha (diakses tanggal 6 Agustus 2017) 